\title{
Synthesis, Anticancer Activity and Computational SAR Analysis of Acylsulfonylpiperazines Derivatives
}

\author{
Zohra Benfodda ${ }^{1 *}$, Vanessa Fritz ${ }^{2 \#}$, Corinne Henriquet ${ }^{3}$, Caterina Fattorusso4, Gerardo Cebrián-Torrejón ${ }^{1}$, Marco Persico ${ }^{4}$, Antonio Di Dato ${ }^{4}$ \\ Marialuisa Menna ${ }^{4}$, Hubert Blancou ${ }^{5}$ and Lluis Fajas ${ }^{6}$ \\ ${ }^{1}$ University of Nîmes, EA7352 CHROME, Rue du Dr G. Salan, 30021 Nîmes Cedex 1, France \\ ${ }^{2}$ The Institute of Molecular Genetics of Montpellier, UMR5535 CNRS, Montpellier, France \\ ${ }^{3}$ Institute of Cancer Research of Montpellier, Campus Val d'Aurelle, Montpellier, France \\ 4University of Naples "Federico II", Department of Pharmacy, Via D. Montesano 49 80131, Naples \\ 5 Institute of Biomolecules Max Mousseron, University of Montpellier, Charles Flahaut, Montpellier, France \\ ${ }^{6}$ Department of Physiology, University of Lausanne, Center for Integrative Genomics, Lausanne, Switzerland \\ \#The authors contribute equally to this work
}

\begin{abstract}
A series of 1-acyl-4-sulfonylpiperazine derivatives has been prepared. The antiproliferative effect of these compounds was evaluated in vitro against human prostate cancer cell line C4-2, several among them exhibited interesting growth inhibitory against this particular cell line. Finally, a molecular modeling study was employed to analyze the structure/activity relationships (SAR) of these novel compounds.
\end{abstract}

Keywords: 1-acyl-4-sulfonylpiperazines; Prostate cancer; Antiproliferative activity; Molecular modelling; SAR

\section{Introduction}

Prostate cancer (PC) is the second most commonly diagnosed cancer in men in western world and is the leading cause of cancer death in elderly $[1,2]$. It is considered a major research and public health priority [3]. Proliferation of cancer cells is at the origin dependent on the action of the hormone responsive androgen receptor, which regulates the expression of genes implicated in the control of metabolism and proliferation of cancer cells. Hormone ablation remains the standard therapy in progressive disease, but unfortunately almost all prostate cancer patients develop hormone refractory prostate cancer (HRPC) and bone metastatic disease. Progression of prostate cancer to androgen independence is the primary barricade in improving patient survival due to complex mechanisms underlying the evolution to androgen independence, and at present, there is no curative treatment for HRPC and bone metastatic disease [4-9]. Development of new drugs with high action against the prostate cancer and with low adverse effects is therefore the most urgent demand to treat cancer $[10,11]$.

In our Laboratory, we have shown that 6-[4-(2-Bromo-5-methoxybenzoyl)-piperazin-1-yl]-N-phenylpropyl nicotinamide (Compound A, Figure 1) induces growth arrest of prostate cancer cell lines in vitro and inhibits LnCap and C4-2 tumour growth in vivo [12].

In continuation of our efforts in search of original molecules with medicinal applications, we decided to design new derivatives of compound A (Figure 1). We have synthesized a novel series of 1-acyl4-sulfonylpiperazine derivatives in order to obtain new anticancer agents which will be active against $\mathrm{C} 4-2$ prostate cancer cells, which are a model of HRPC [13]. Piperazines and substituted piperazines are important pharmacophores that are found in many drugs [14]. Piperazine scaffold acts on different pharmacological targets and is present in a broad range of biological active compounds, including several molecules against cancer [15-21], dual calcium antagonists [22], compounds with effects on dopaminergic neurotransmission [23] and HIV protease inhibitors [24,25].

Preliminary bioassays indicated that compounds $4 \mathbf{i}, 4 \mathbf{k}, 4 \mathrm{~m}, \mathbf{4 p}$ displayed an interesting antiproliferative activity on prostate cancer C4-2 cells. Finally, the structure activity relationship (SAR) was studied.

\section{Experimental Methods}

\section{Chemistry}

Reagents were obtained from Sigma-Aldrich or Acros. Solvents were distilled from the appropriate drying agents immediately prior to use. ${ }^{1} \mathrm{H},{ }^{19} \mathrm{~F}$, and ${ }^{13} \mathrm{C}$ NMR spectra were recorded at $300.13 \mathrm{MHz}, 282.37 \mathrm{MHz}$ and $75.46 \mathrm{MHz}$ respectively with a Brucker Avance 300 spectrometer; the chemical shifts are given in ppm relative to $\mathrm{Me}_{4} \mathrm{Si}$ for the ${ }^{1} \mathrm{H}$ and ${ }^{13} \mathrm{C}$, and $\mathrm{CCl}_{3} \mathrm{~F}$ for ${ }^{19} \mathrm{~F}$, as internal standards. Coupling constants were given in Hz. High Resolution Mass Spectrometry (HRMS) were recorded on a Jeol SX 102 spectrometer.

Melting points were recorded at atmospheric pressure unless otherwise stated on a Stuart scientific SMP3 apparatus and were uncorrected. The products were purified by column chromatography. Thin layer chromatography was performed with Merck Silica gel aluminium-backed plate with UV visualization. The following synthetic conditions have not been optimized.

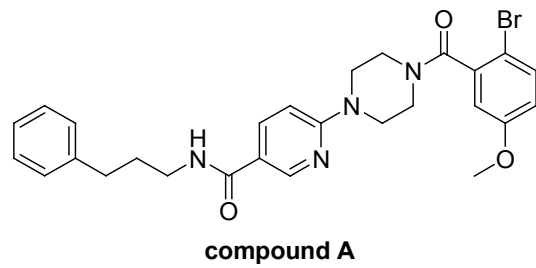

Figure 1: Compound A.

*Corresponding author: Zohra Benfodda, University of Nîmes, EA7352 CHROME, Rue du Dr G. Salan, 30021 Nîmes Cedex 1, France, Tel: 0467143843 E-mail: zohra.benfodda@unimes.fr

Received September 15, 2016; Accepted September 26, 2017; Published September 29, 2017

Citation: Benfodda Z, Fritz V, Henriquet C, Fattorusso C, Cebrián-Torrejón G, et al. (2017) Synthesis, Anticancer Activity and Computational SAR Analysis of Acylsulfonylpiperazines Derivatives. Med Chem (Los Angeles) 7: 257-267. doi: 10.4172/2161-0444.1000466

Copyright: (c) 2017 Benfodda Z, et al. This is an open-access article distributed under the terms of the Creative Commons Attribution License, which permits unrestricted use, distribution, and reproduction in any medium, provided the original author and source are credited. 
Synthesis of tert-butyl-1-piperazinecarboxylate (1): In a 1000 $\mathrm{mL}$ flask were added $370 \mathrm{~mL}$ of $\mathrm{CH}_{2} \mathrm{Cl}_{2}$ and $12.63 \mathrm{~g}$ (147 mmol) of piperazine. To the resulting solution, maintained at $0^{\circ} \mathrm{C}$ using an ice bath, was added dropwise a di-tert- butyldicarbonate solution ( $16 \mathrm{~g}, 73.5$ $\mathrm{mmol}$ in $150 \mathrm{~mL}$ of $\mathrm{CH}_{2} \mathrm{Cl}_{2}$ ). The mixture was stirred for additionnal hour, filtered and the filtrate concentrated to dryness. Water $(220 \mathrm{~mL})$, was added to the resulting oil and the mixture filtered. The filtrate was saturated with potassium carbonate and extracted with diethyl ether $(3 \times 100 \mathrm{~mL})$. The solvent was dried over $\mathrm{Na}_{2} \mathrm{SO}_{4}$ and concentrated to dryness yielding to $9 \mathrm{~g}$ of 1 (oil, 66\%).

${ }^{1} \mathrm{H}$ NMR (300.13 MHz, $\left.\mathrm{CDCl}_{3}\right): \delta 1.35$ (s, 9H, Boc), 2.10 (br, $1 \mathrm{H}$, $\mathrm{NH}), 2.70\left(\mathrm{t}, \mathrm{J}=4.8 \mathrm{~Hz}, 4 \mathrm{H}, 2 \mathrm{CH}_{2}\right), 3.30\left(\mathrm{t}, \mathrm{J}=4.9 \mathrm{~Hz}, 4 \mathrm{H}, 2 \mathrm{CH}_{2}\right)$.

Synthesis of tert-butyl-4-(2-bromo-5-methoxybenzoyl) piperazine-1-carboxylate (2): 2-bromo-5-methoxybenzoic acid (12 $\mathrm{g}, 52 \mathrm{mmol}$ ) and thionyl chloride were refluxed for $3 \mathrm{~h}$. The excess of thionyl chloride was removed by distillation in vacuo to give dark oil (12.9 g, 99\%). To a solution of tert-butyl-1-piperazine carboxylate (8.7 $\mathrm{g}, 47 \mathrm{mmol})$ and DIPEA $(13.6 \mathrm{~mL}, 78 \mathrm{mmol})$ in $\mathrm{CH}_{2} \mathrm{Cl}_{2}$ at $0^{\circ} \mathrm{C}$, was added 2-bromo-5-methoxybenzoyl chloride $(12.96 \mathrm{~g}, 52 \mathrm{mmol})$. The reaction mixture was stirred at room temperature for $2 \mathrm{~h}$. The progress of reaction was monitored by TLC. Upon completion, the crude product was taken in water and extracted with $\mathrm{CH}_{2} \mathrm{Cl}_{2}$. The organic layer was dried over anhydrous $\mathrm{Na}_{2} \mathrm{SO}_{4}$ and concentrated under reduced pressure. The crude material was purified by column chromatography (Petroleum ether/Ethyl acetate; 70:30) to give compound 2 (16 g, 85\%). $R_{f} 0.25$ (Petroleum ether/Ethyl acetate; 70:30).

${ }^{1} \mathrm{H}$ NMR (300.13 MHz, $\left.\mathrm{CDCl}_{3}\right): \delta 1.35$ (s, 9H, Boc), 3.10-3.30 (m, $\left.3 \mathrm{H}, \mathrm{CH}, \mathrm{CH}_{2}\right), 3.45\left(\mathrm{~m}, 3 \mathrm{H}, \mathrm{CH}, \mathrm{CH}_{2}\right), 3.60(\mathrm{~m}, 1 \mathrm{H}, \mathrm{CH}), 3.70(\mathrm{~s}, 3 \mathrm{H}$, $\left.\mathrm{OCH}_{3}\right), 3.80(\mathrm{~m}, 1 \mathrm{H}, \mathrm{CH}), 6.70\left(\mathrm{~m}, 2 \mathrm{H}, 2 \mathrm{CH}_{\mathrm{Ar}}\right), 7.30(\mathrm{~d}, \mathrm{~J}=8.5 \mathrm{~Hz}$, $\left.1 \mathrm{H}, \mathrm{CH}_{\mathrm{Ar}}\right) ;{ }^{13} \mathrm{C} \mathrm{NMR}\left(75.46 \mathrm{MHz}, \mathrm{CDCl}_{3}\right): \delta 28.1,28.3,28.6,41.5(2 \mathrm{C})$, 46.6(2C), 55.6, 80.3, 109.2, 113.0, 116.6, 133.7, 138.3, 154.4, 159.2, 167.6.

Synthesis of 1N-(2-bromo-5-methoxybenzoyl)piperazine (3): Trifluoroacetic acid $(15 \mathrm{~mL})$ was added slowly at $0-5^{\circ} \mathrm{C}$ under nitrogen to a solution of tert-butyl-4-(2-bromo-5-methoxybenzoyl)piperazine1-carboxylate $(16 \mathrm{~g}, 40 \mathrm{mmol})$ in $\mathrm{CH}_{2} \mathrm{Cl}_{2}(15 \mathrm{~mL})$. The mixture was stirred at room temperature for $2 \mathrm{~h}$ then poured in cold water $(50$ $\mathrm{mL}$ ). The aqueous solution was made basic by the addition of $\mathrm{NaOH}$ $(1 \mathrm{~N})$, then the product was extracted with $\mathrm{CH}_{2} \mathrm{Cl}_{2}(2 \times 100 \mathrm{~mL})$. The combined extracts were washed with brine $(200 \mathrm{~mL})$, dried over anhydrous $\mathrm{Na}_{2} \mathrm{SO}_{4}$ and concentrated under reduced pressure yielding to $10.2 \mathrm{~g}(85 \%)$ of the title compound.

${ }^{1} \mathrm{H}$ NMR (300.13 MHz, $\left.\mathrm{CDCl}_{3}\right): \delta 2.10(\mathrm{br}, 1 \mathrm{H}, \mathrm{NH}), 2.65(\mathrm{~m}, 1 \mathrm{H}$, $\mathrm{CH}), 2.85\left(\mathrm{~m}, 3 \mathrm{H}, \mathrm{CH}, \mathrm{CH}_{2}\right), 3.15\left(\mathrm{~m}, 2 \mathrm{H}, \mathrm{CH}_{2}\right), 3.70\left(\mathrm{~m}, 5 \mathrm{H}, \mathrm{CH}_{2}\right.$, $\left.\mathrm{OCH}_{3}\right), 6.70\left(\mathrm{~m}, 2 \mathrm{H}, 2 \mathrm{CH}_{\mathrm{Ar}}\right), 7.30\left(\mathrm{~m}, 1 \mathrm{H}, \mathrm{CH}_{\mathrm{Ar}}\right) ;{ }^{13} \mathrm{C}$ NMR $(75.46$ $\left.\mathrm{MHz}, \mathrm{CDCl}_{3}\right): \delta 41.6,46.8,50.8,51.4,55.7,109.3,113.0,116.5,133.6$, 138.6, 159.3, 167.4.

Synthesis of $1 \mathrm{~N}-[(2-$ bromo-5-methoxybenzoyl $)]-4 \mathrm{~N}$ [(substituted phenyl)sulfonyl]piperazine (4a-4x)

General procedure: To a solution of 3 (1 equiv.) and DIPEA (1.5 equiv.) in anhydrous $\mathrm{CH}_{2} \mathrm{Cl}_{2}(20 \mathrm{~mL})$ at $0^{\circ} \mathrm{C}$ was added substituted phenyl or heteroarylsulfonyl chloride ( 1 equiv.). The mixture was stirred overnight at room temperature. Reaction was monitored by TLC. After completion, the reaction mixture was diluted with $\mathrm{CH}_{2} \mathrm{Cl}_{2}$, washed with water and then with brine. The organic layer was dried over anhydrous $\mathrm{Na}_{2} \mathrm{SO}_{4}$ and concentrated under reduced pressure. The crude material was purified by column chromatography or by recrystallization from acetone to give the corresponding piperazine derivatives $(\mathbf{4 a}-\mathbf{4 x})$.

Synthesis of $1 \mathrm{~N}-[(2-$ bromo-5-methoxybenzoyl $)]-4-[(4-$ bromophenyl)sulfonyl]piperazine (4i): The crude product was crystallized from acetone to give pure product $(0.56 \mathrm{~g})$

White crystal. ${ }^{1} \mathrm{H}$ NMR $\left(300.13 \mathrm{MHz}, \mathrm{CDCl}_{3}\right): \delta 2.90(\mathrm{~m}, 1 \mathrm{H}), 3.05$ (m, 3H), 3.15-3.35 (m, 2H), $3.65\left(\mathrm{~s}, 3 \mathrm{H}, \mathrm{OCH}_{3}\right), 3.70(\mathrm{~m}, 1 \mathrm{H}), 3.85(\mathrm{~m}$, $1 \mathrm{H}), 6.60(\mathrm{~d}, \mathrm{~J}=3 \mathrm{~Hz}, 1 \mathrm{H}), 6.75(\mathrm{dd}, \mathrm{J}=8.9 \mathrm{~Hz}, 3 \mathrm{~Hz}, 1 \mathrm{H}), 7.30(\mathrm{~d}, 1 \mathrm{H})$, $7.50(\mathrm{~d}, \mathrm{~J}=2.3 \mathrm{~Hz}, 2 \mathrm{H}), 7.65(\mathrm{~d}, \mathrm{~J}=2.3 \mathrm{~Hz}, 2 \mathrm{H}) ;{ }^{13} \mathrm{C} \mathrm{NMR}(75.46 \mathrm{MHz}$, $\mathrm{CDCl}_{3}$ ): $\delta 40.9,45.6,46,46.1,55.7,109.1,113.2,116.7,128.4,129.1$ (2C), 132.6 (2C), 133.7, 134.6, 137.7, 159.2, 167.4; HRMS (ESI) calc for $[\mathrm{M}+\mathrm{H}]^{+} \mathrm{C}_{18} \mathrm{H}_{19} \mathrm{~N}_{2} \mathrm{O}_{4} \mathrm{SBr}_{2} 516.9432$ obsd 516.9438 .

Synthesis of $1 N-[(2-b r o m o-5-m e t h o x y b e n z o y l)]-4 N-[(2-$ trifluoromethylphenyl)sulfonyl]piperazine (4k): The crude product was purified by column chromatography (Cyclohexane/Ethyl acetate $50: 50)$ to give compound $(0.51 \mathrm{~g}) . R_{f}=0.37$ (Cyclohexane/Ethyl acetate 50:50).

White powder. ${ }^{1} \mathrm{H}$ NMR $\left(300.13 \mathrm{MHz}, \mathrm{CDCl}_{3}\right): \delta 3.15-3.45(\mathrm{~m}$, $6 \mathrm{H}), 3.75(\mathrm{~m}, 4 \mathrm{H}), 4.05(\mathrm{~m}, 1 \mathrm{H}), 6.75(\mathrm{~d}, \mathrm{~J}=3 \mathrm{~Hz}, 1 \mathrm{H}), 6.80(\mathrm{dd}, \mathrm{J}=8.8$ $\mathrm{Hz}, 3 \mathrm{~Hz}, 1 \mathrm{H}), 7.45$ (d, J=8.8 Hz, 1H), $7.70(\mathrm{~m}, 2 \mathrm{H}), 7.85$ (m, 1H), 8.05 $(\mathrm{m}, 1 \mathrm{H}) ;{ }^{13} \mathrm{C}$ NMR $\left(75.46 \mathrm{MHz}, \mathrm{CDCl}_{3}\right): \delta 39.7,43.7,44,45,54.1,107.6$, 111.6, 115.3, $120.9\left(\mathrm{CF}_{3}, \mathrm{~J}=274 \mathrm{~Hz}\right), 126.6\left(\mathrm{C}_{-} \mathrm{CF}_{3}, \mathrm{~J}=33 \mathrm{~Hz}\right), 127.2(\mathrm{CH}$, $\mathrm{J}=6.8 \mathrm{~Hz}), 130.6,130.8,131.6,132.2,135.7,136.3,157.7,166 ;{ }^{19} \mathrm{~F}$ NMR $\left(282.4 \mathrm{MHz}, \mathrm{CDCl}_{3}\right): \delta-57.47(\mathrm{~m}, 3 \mathrm{~F})$; HRMS (ESI) calc for $[\mathrm{M}+\mathrm{H}]^{+}$ $\mathrm{C}_{19} \mathrm{H}_{19} \mathrm{~N}_{2} \mathrm{O}_{4} \mathrm{SBrF}_{3} 507.0201$ obsd 507.0185.

Synthesis of $1 \mathrm{~N}-[(2-$ bromo-5-methoxybenzoyl $)]-4 \mathrm{~N}[(4-$ trifluoromethylphenyl)sulfonyl]piperazine $(4 \mathrm{~m})$ : The crude product was purified by column chromatography (Cyclohexane/Ethyl acetate $50: 50)$ to give compound $(0.6 \mathrm{~g}) . R_{f}=0.49$ (Cyclohexane/Ethyl acetate 50:50).

White powder. ${ }^{1} \mathrm{H}$ NMR $\left(300.13 \mathrm{MHz}, \mathrm{CDCl}_{3}\right): \delta 2.90(\mathrm{~m}, 1 \mathrm{H})$, 3.05-3.15 (m, 3H), 3.20-3.40 (m, $2 \mathrm{H}), 3.70\left(\mathrm{~s}, 3 \mathrm{H}, \mathrm{OCH}_{3}\right), 3.75(\mathrm{~m}, 1 \mathrm{H})$ $3.90(\mathrm{~m}, 1 \mathrm{H}), 6.65(\mathrm{~d}, \mathrm{~J}=3 \mathrm{~Hz}, 1 \mathrm{H}), 6.70(\mathrm{dd}, \mathrm{J}=8.8 \mathrm{~Hz}, 3 \mathrm{~Hz}, 1 \mathrm{H}), 7.35$ $(\mathrm{d}, \mathrm{J}=8.8 \mathrm{~Hz}, 1 \mathrm{H}), 7.70-7.90(\mathrm{~m}, 4 \mathrm{H}) ;{ }^{13} \mathrm{C}$ NMR $\left(75.46 \mathrm{MHz}, \mathrm{CDCl}_{3}\right): \delta$ 38.4, 43.1, 43.5, 43.6, 53.2, 106.5, 110.7, 114.2, $120.62\left(\mathrm{q}, \mathrm{CF}_{3}, \mathrm{~J}=273.2\right.$ $\mathrm{Hz}), 124(2 \mathrm{C}), 125.7(2 \mathrm{C}), 131.3,132.4\left(\mathrm{C}-\mathrm{CF}_{3}, \mathrm{q}, \mathrm{J}=33 \mathrm{~Hz}\right), 135.1,136.9$, 156.7, 165.0; ${ }^{19} \mathrm{~F}$ NMR (282.4 MHz, $\left.\mathrm{CDCl}_{3}\right): \delta$ - 63.11 (m, 3F); HRMS (ESI) calc for $[\mathrm{M}+\mathrm{H}]^{+} \mathrm{C}_{19} \mathrm{H}_{19} \mathrm{~N}_{2} \mathrm{O}_{4} \mathrm{SBrF}_{3} 507.0201$ obsd 507.0184.

Synthesis of $1 \mathrm{~N}-[(2-$ bromo-5-methoxybenzoyl $)]-4 N-[(4-$ isopropylphenyl)sulfonyl]piperazine (4p): The crude product was purified by column chromatography (Petroleum ether/Ethyl acetate 50:50) to give compound (0.55 g). $R_{f} 0.52$ (Petroleum ether/Ethyl acetate 50:50).

White powder. ${ }^{1} \mathrm{H}$ NMR $\left(300.13 \mathrm{MHz}, \mathrm{CDCl}_{3}\right): \delta 1.25(\mathrm{~s}, 6 \mathrm{H})$, 2.9-3.15 (m, 5H), 3.2-3.4 (m, $2 \mathrm{H}), 3.65\left(\mathrm{~s}, 3 \mathrm{H}, \mathrm{OCH}_{3}\right), 3.7(\mathrm{~m}, 1 \mathrm{H})$, $3.85(\mathrm{~m}, 1 \mathrm{H}), 6.60(\mathrm{~d}, \mathrm{~J}=3 \mathrm{~Hz}, 1 \mathrm{H}), 6.70(\mathrm{dd}, \mathrm{J}=8.8 \mathrm{~Hz}, 3 \mathrm{~Hz}, 1 \mathrm{H}), 7.40$ $(\mathrm{m}, 3 \mathrm{H}), 7.65(\mathrm{~d}, \mathrm{~J}=8.4 \mathrm{~Hz}, 2 \mathrm{H}) ;{ }^{13} \mathrm{C}$ NMR $\left(75.46 \mathrm{MHz}, \mathrm{CDCl}_{3}\right): \delta 23.6$ (2 C), 34.2, 41, 45.6, 46.1 (2C), 55.6, 109.1, 113.1, 116.6, 127.3 (2C), 127.9 (2C), 132.5, 133.7, 137.8, 154.8, 159.2, 167.4; HRMS (ESI) calc for $[\mathrm{M}+\mathrm{H}]^{+} \mathrm{C}_{21} \mathrm{H}_{26} \mathrm{~N}_{2} \mathrm{O}_{4} \mathrm{SBr} 481.0797$ obsd 481.0791 .

\section{Biology}

Cell culture: The androgen-independent C4-2 human prostate carcinoma cell line was purchased from American Type Culture Collection (Manassas, VA). Monolayer cell cultures were maintained in a RPMI 1640 media M l-glutamine (Invitrogen, Cergy, France) supplemented with $10 \%$ fetal calf serum (FCS), $100 \mathrm{U} / \mathrm{ml}$ penicillin, $100 \mu \mathrm{g} / \mathrm{ml}$ streptomycin, $10 \mathrm{mM}$ HEPES and $1.0 \mathrm{mM}$ sodium pyruvate (Invitrogen) at $37^{\circ} \mathrm{C}$ in $5 \% \mathrm{CO}_{2}$. 
BrDU staining: C4-2 cells were grown on cover slips and were incubated with the indicated compounds at $25 \mu \mathrm{M}$ in DMSO. Following $44 \mathrm{~h}$ of treatment, the cells were then incubated for 4 more hours with 5-bromo-2-deoxyuridine (BrdU) at $100 \mu \mathrm{M}$ final (Sigma Aldrich, Saint Quentin Fallavier, France). Cells were then fixed and permeabilized with cold methanol for $10 \mathrm{~min}$ at $-20^{\circ} \mathrm{C}$. After 3 washes with PBS, DNA was denaturated with $4 \mathrm{~N}$ HCL for $10 \mathrm{~min}$ at RT, and cells were incubated with blocking buffer (PBS- $1 \%$ BSA). BrDU was then detected with anti-BrDU monoclonal antibody 1:50 (Dako, Carpinteria, CA) for 1 hour at $37^{\circ} \mathrm{C}$. After 3 washes with PBS, cells were incubated with an FITC-conjugated anti-mouse secondary antibody 1:150 (Jackson Immunoresearch) for $30 \mathrm{~min}$ at $37^{\circ} \mathrm{C}$, and slides were mounted in mowiol. The percentages of proliferating BrdU-positive cells were counted. Experiment were done in duplicate and are expressed as the mean \pm sem percentage decrease of proliferating BrdU-positive cells as compared to control cells treated with DMSO only.

Statistical analysis: Statistical analysis were performed with unpaired Student's t-test. Differences were considered statistically significant at $\mathrm{p}<0.05\left({ }^{*} \mathrm{p}<0.05 ;{ }^{* *} \mathrm{p}<0.01\right.$ and $\left.{ }^{* *} \mathrm{p}<0.001\right)$.

\section{Molecular modeling}

Molecular modeling calculations were performed on E4 Server Twin $2 \times$ Dual Xeon-5520, equipped with two nodes. Each node: $2 \mathrm{x}$ Intel $^{\circ} \mathrm{Xeon}^{\oplus}$ QuadCore E5520-2.26Ghz, 36 GB RAM. The molecular modeling graphics were carried out on a personal computer equipped with Intel(R) Core(TM) i7-4790 processor and SGI Octane 2 workstations.

The apparent $\mathrm{pKa}$ and $\log \mathrm{D}$ values ( $\mathrm{pH}$ 7.2) of the newly designed compounds $\mathbf{4 a - x}$ were calculated by using the ACD/Percepta software (ACD/Percepta, Advanced Chemistry Development, Inc., Toronto, ON, Canada, 2015, http://www.acdlabs.com.). All compounds were considered neutral in all calculations performed as a consequence of the estimation of percentage of neutral/ionized forms computed at $\mathrm{pH}$ 7.2 (cytoplasm pH value), using the Handerson-Hasselbalch equation.

Compounds 4a-x were built and, then, subjected to molecular mechanic $(\mathrm{MM})$ energy minimization $\left(\varepsilon=80^{\star} \mathrm{r}\right)$ until the maximum RMS derivative was less than $0.001 \mathrm{kcal} / \AA ̊$, using Conjugate Gradient [26] as minimization algorithm (Discovery Studio 2017; Dassault System BIOVIA, San Diego, 2016). Atomic potentials and charges were assigned using the CFF forcefield [27]. The conformers obtained for each compound were used as starting structure for the subsequent systematic conformational analysis (Search Small Molecule Conformations; Discovery Studio 2017). The conformational space of the compounds was sampled considering possible piperazine ring conformations, as well as, the two orientation of the amide bond, and by systematically varying all rotatable bonds $(\tau 1, \tau 2, \tau 3$ and $\tau 4)$ with an increment of $60^{\circ} \mathrm{C}$. In the case of compounds $4 \mathbf{c}, 4 \mathbf{n}, 4 \mathbf{o}, 4 \mathbf{p}, 4 \mathbf{r}$, and $4 \mathrm{t}$ the rotatable bonds of the $\mathrm{R}_{1}$ substituent were also systematically varied. The RMSD cutoff for structure selection was set to 0.01 ( $\AA$ ). Finally, to ensure a wide variance of the input structures to be successively fully minimized, an energy threshold value of $10^{6} \mathrm{kcal} / \mathrm{mol}$ was used as selection criteria. The generated structures were then subjected to $\mathrm{MM}$ energy minimization (CFF forcefield; $\varepsilon=80^{\star} \mathrm{r}$ ) until the maximum RMS derivative was less than $0.001 \mathrm{kcal} / \AA$, using Conjugate Gradient as minimization algorithm. Finally, the resulting conformers were ranked by their potential energy values (i.e., $\Delta E$ from the global energy minimum) and grouped into conformational families on the basis of dihedral angle values.

The global minimum conformer of each compound and the minimum conformers of the $\mathrm{II}_{\mathrm{B}}, \mathrm{III}_{\mathrm{B}}$, and $\mathrm{IV}_{\mathrm{B}}$ families of $4 \mathrm{a}$, of the $\mathrm{I}_{\mathrm{E}}$ and
$\mathrm{IV}_{\mathrm{B}}$ families of $\mathbf{4 b}$, of $\mathrm{IV}_{\mathrm{B}}$ family of $4 \mathbf{c}$, of the $\mathrm{II}_{\mathrm{A}}$, III $\mathrm{D}_{\mathrm{D}}$, and $\mathrm{IV}_{\mathrm{D}}$ families of $4 \mathbf{e}$, of $\mathrm{IV}_{B}$ family of $4 \mathbf{h}$, of the $\mathrm{I}_{A}, \mathrm{I}_{C}, \mathrm{II}_{A}, \mathrm{III}_{B}, \mathrm{I}$ and $\mathrm{V}_{\mathrm{D}}$ families of $\mathbf{4 k}$, of $\mathrm{IV}_{\mathrm{D}}$ family of $4 \mathbf{l}$, of the $\mathrm{II}_{\mathrm{A}}$ and $\mathrm{III}_{\mathrm{B}}$ families of $4 \mathbf{o}$, of $\mathrm{IV}_{\mathrm{B}}$ family of $\mathbf{4 p}$, of $I V_{B}$ family of $4 s$ and of $I V_{D}$ family of $4 w$ have been then subjected to DFT calculations. The calculations were carried out using the Gaussian 09 package [28]. All structures were fully optimized in gas-phase at the B3LYP/6-31+G(d,p) level $[29,30]$. In order to characterize every structure as minimum, a vibrational analysis was carried out at the same level of theory, using the keyword freq. The RMS force criterion was set to $3 \times 10^{-4}$ a.u. Molecular charge distribution has been calculated using the natural bond orbital (NBO) method [31]. The atomic charges, derived from the NBO population analysis were used to calculate the dipole moment of the substituent $R_{1}$.

\section{Results and Discussion}

\section{Chemistry}

The synthesis of 1-acyl-4-sulfonylpiperazine derivatives $4 \mathbf{a}-\mathbf{x}$ is shown in Scheme 1. Tert-butyl-1-piperazinecarboxylate (1) was prepared from piperazine and from di-tert-butyldicarbonate. Acylation with 2-bromo 5-methoxybenzoyl chloride of (1) in the presence of DIPEA led to tert-butyl-4-(2-bromo-5-methoxybenzoyl)piperazine1-carboxylate (2). The tert-butyloxycarbonyl (Boc) deprotection with trifluoroacetic acid resulted in 1-N-(2-bromo-5-methoxybenzoyl) piperazine (3). The nucleophilic substitution reactions of $1-\mathrm{N}-(2-$ bromo-5-methoxybenzoyl)piperazine (3) with different aryl and heteroarylsulfonyl chlorides $\left(\mathrm{RSO}_{2} \mathrm{Cl}\right)$, in the presence of diisopropylethylamine (DIPEA) and dichloromethane $\left(\mathrm{CH}_{2} \mathrm{Cl}_{2}\right)$ as solvent at $0^{\circ} \mathrm{C}$ to room temperature gave the 1 -acyl-4-sulfonylpiperazine derivatives (4a-x) in a moderate to good yields ranging from 60 to $81 \%$ (Scheme 1).

The presence of $\mathrm{NH}$ proton at $2.1 \delta$ value in starting material piperazine (3) and the absence of this proton peak in ${ }^{1} \mathrm{H}$ NMR spectra confirm our products (4a-x). The 1-acyl-4-sulfonylpiperazine derivatives (4a-x) were purified by column chromatography using cyclohexane: ethyl acetate $(6: 4$; or $5: 5 ; 3: 7)$ or petroleum ether : ethyl acetate $(7: 3 ; 5: 5)$ as eluent or by recrystallization in acetone. All the newly prepared compounds (4a-x) were given with corrected analytical data. The ${ }^{1} \mathrm{H},{ }^{19} \mathrm{~F},{ }^{13} \mathrm{C}$ NMR spectra data, HRMS data were consistent with the assigned structure. The chemical structure of each compound is reported in Table 1.

\section{Antiproliferative activity}

It was previously reported that piperazine derivatives show

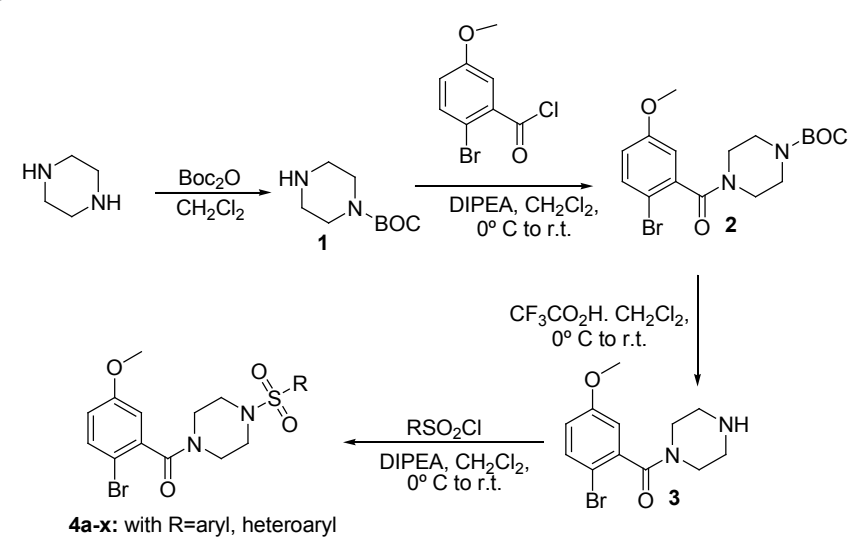

Scheme 1: Synthesis of piperazine derivatives $4 a-x$. 
antiproliferative activity against many cancer cells [32-34]. In order to search for new compounds with antiproliferative activity against prostate cancer, all new synthesized compounds $(\mathbf{4} \mathbf{a}-\mathbf{x})$ were evaluated for their in vitro antiproliferative activities against the human androgenindependent prostate cancer cell line C4-2, using BrdU incorporation assay. The growth inhibition activity against C4-2 cells is depicted in Table 2 for all compounds at the concentration of $25 \mu \mathrm{M}$. At the tested concentration compounds $4 \mathbf{i}, \mathbf{4 k}, \mathbf{4 m}, \mathbf{4} \mathbf{p}$ exhibited the strongest antiproliferative activity against the C4-2 cells (Table 2). Interestingly, the results revealed that the nature of the substituent and substitution pattern on the benzene ring binding to sulfonyl group-might have a considerable impact on the antiproliferative activity of the synthesized compounds. Interestingly, the compound with $\mathrm{CF}_{3}$ ortho-substitution on the benzene ring $\mathbf{4} \mathbf{k}$ showed the best inhibition properties whereas the $\mathrm{CF}_{3}$ meta and para-substitution $(\mathbf{4 1}, \mathbf{4 m}$ respectively) on the benzene ring were less active in the inhibition of the proliferation of C4-2 cells.

The introduction of the para $\mathrm{O}-\mathrm{CF}_{3}$ substitution $4 \mathbf{n}$ on the benzene ring gave the similar inhibitory activity than compound $\mathbf{4 m}$. In addition, para-substitution of respectively $\mathrm{CF}_{3}$ and $\mathrm{OCF}_{3}$ groups in $\mathbf{4 m}$ and $\mathbf{4 n}$ was more efficient than para-substitution of $\mathrm{CH}_{3}$ or $\mathrm{OCH}_{3}$ groups in $\mathbf{4 q}$ and $\mathbf{4 t}$, as far as inhibitory activity was concerned. Within the few variations considered in this study, the presence of trifluoromethyl group afforded a clear beneficial effect with regard to antiproliferative properties. The para-bromine substitution $4 \mathbf{i}$ led to a more pronounced antiproliferative activity than the para-fluorine $\mathbf{4 d}$ and para-chlorine substitutions $4 \mathbf{j}$. The introduction of a second fluorine atom in orthoposition on the benzene ring in the compound $4 \mathrm{e}$ decreased dramatically the activity of compound $\mathbf{4 h}$. The substitution of the benzene ring by an heterocyclic ring $\mathbf{4 u - x}$ led to less antiproliferative activity. Compounds $\mathbf{4 h}, \mathbf{4 q}, 4 \mathbf{s}$ were failed to exhibit significant effect on tumoral C4-2 cells.

\section{Computational studies and SAR analysis}

The conformational space of compounds $\mathbf{4 a - x}$ was sampled by means of a systematic conformational search including all rotatable bonds, coupled with molecular mechanic (MM) optimization of the resulting conformations. MM calculations were performed by using the CFF force field [27] for atom parametrization and a distance dependent dielectric constant with a value of 80 to mimic an aqueous environment (Discovery Studio 2017, BIOVIA, San Diego USA; see the Experimental Section for details). The results obtained allowed us to identify all energy minimum structures of compounds $\mathbf{4 a - x}$ and, in particular, their global minimum (GM) conformers.

All conformers within $5 \mathrm{kcal} / \mathrm{mol}$ from the GM were, then, selected and classified in to families according to the values of their torsion angles (Tables S1-S24). In all the resulting families, the piperazine ring assumes a chair-like conformation. The rotation about the amide bond is accompanied by piperazine chair inversion and generates two parallel sets of conformers, which resulted to be the mirror image of each other and show the same conformational energy, thus behaving as conformational enantiomers (Figure 2).

On the other hand, the rotation about the N-S bond $(\tau 1)$ gave rise to four families of conformers, herein named I-IV (Figure 3).

The resulting family of conformers can be further classified in to sub-families on the basis of the rotation of the aromatic ring $\mathrm{R}$ and the varied substituent $R_{1}$. In particular, regarding the orientation of $R_{1}$, when it is a ortho- and meta-substituted phenyl ring, as well as, a benzyl or a heterocycle (i.e., $\mathbf{4 b}, \mathbf{4 e - g}, \mathbf{4 k}, \mathbf{4 l}, \mathbf{4} \mathbf{u}-\mathbf{x}$; Table 2) two main sets of equilibrium positions were identified within each family, characterized

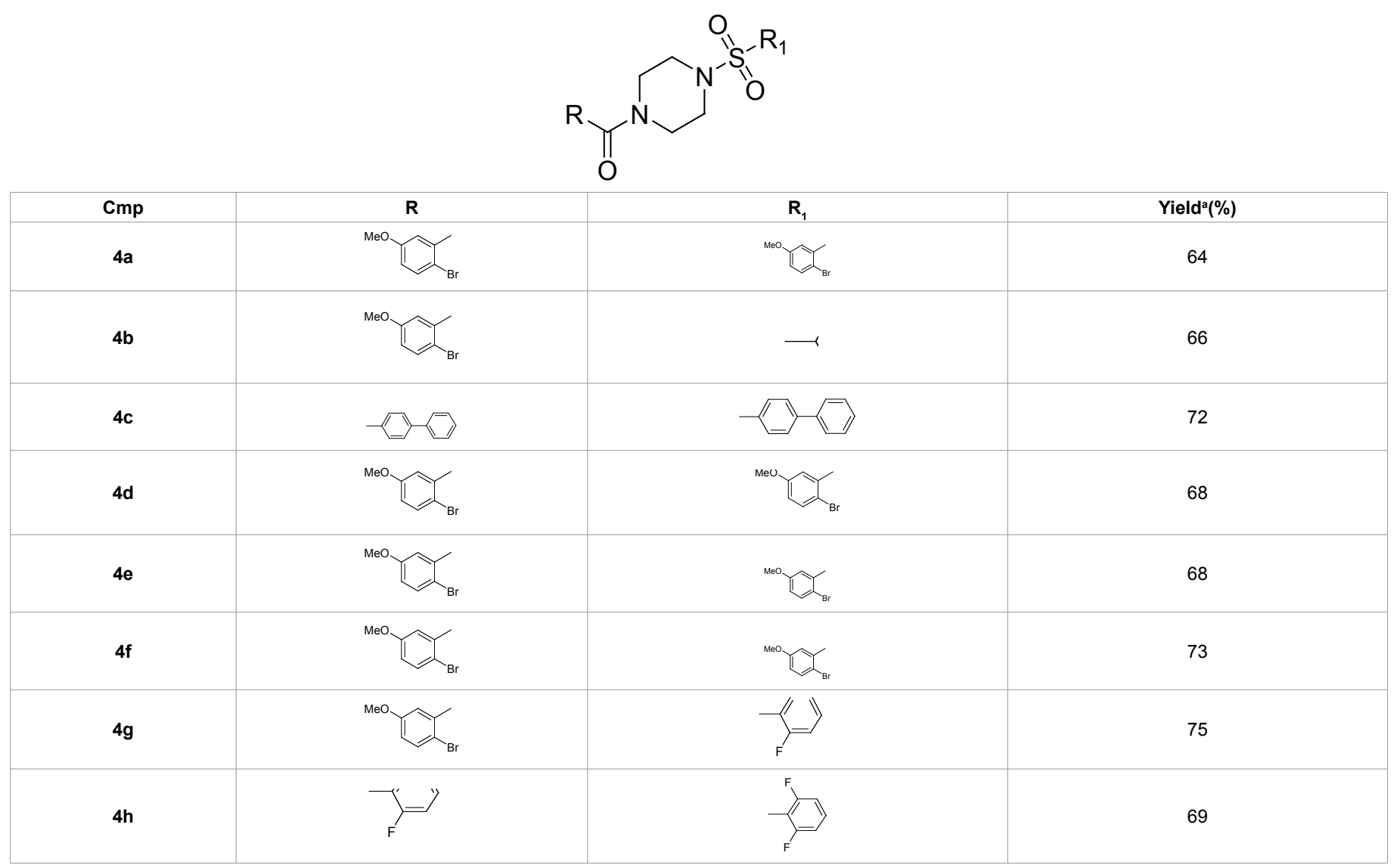


Citation: Benfodda Z, Fritz V, Henriquet C, Fattorusso C, Cebrián-Torrejón G, et al. (2017) Synthesis, Anticancer Activity and Computational SAR Analysis of Acylsulfonylpiperazines Derivatives. Med Chem (Los Angeles) 7: 257-267. doi: 10.4172/2161-0444.1000466

\begin{tabular}{|c|c|c|c|}
\hline Cmp & $\mathbf{R}$ & $\mathbf{R}_{1}$ & Yielda(\%) \\
\hline $4 i$ & & & 65 \\
\hline $4 j$ & & & 63 \\
\hline $4 k$ & & & 60 \\
\hline 41 & & & 81 \\
\hline $4 m$ & & & 71 \\
\hline $4 n$ & & & 69 \\
\hline 40 & & & 77 \\
\hline $4 p$ & & & 68 \\
\hline $4 q$ & & & 67 \\
\hline $4 r$ & & & 68 \\
\hline $4 \mathrm{~s}$ & & & 77 \\
\hline $4 t$ & & & 66 \\
\hline $4 u$ & & & 72 \\
\hline $4 v$ & & & 67 \\
\hline $4 w$ & & & 64 \\
\hline $4 x$ & & & 72 \\
\hline
\end{tabular}

aYields obtained after purification of all compounds by column chromatography or by recrystallization.

Table 1: Chemical structure, physical data of synthesized compounds (4a-4x).

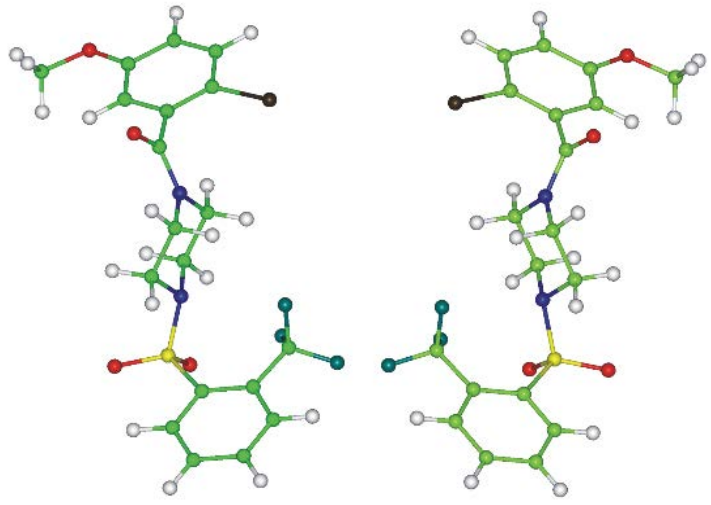

Figure 2: The two global minimum conformers of $\mathbf{4 k}$. Hydrogens are omitted for clarity of presentation. by negative or positive values of the corresponding torsion angle (named $\tau 2$ ). The same is valid also for rotation of the di-substituted phenyl ring $\mathrm{R}$ (torsion angle named $\tau 3$ ). Accordingly, families I-IV were further classified in to sub-families $A-D$ according to the values of $\tau 2$ and $\tau 3$ torsion angles $(A=\tau 2+/ \tau 3+, B=\tau 2+/ \tau 3-, C=\tau 2-/ \tau 3+$, $\mathrm{D}=\tau 2-/ \tau 3-$; just for $\left.\mathbf{4 b}: \mathrm{A}_{180}=\tau 2180 / \tau 3+, \mathrm{B}_{180}=\tau 2180 / \tau 3-\right)$. It has to be underlined that in the cases in which $\mathrm{R}_{1}$ is $\mathrm{i}$ ) an unsubstituted phenyl ring (4a), ii) a para-substituted phenyl ring (4c, $4 \mathbf{d}, \mathbf{4 i}, \mathbf{4 j}$, and $\mathbf{4 m - t})$, or iii) a 2,5-disubstituted phenyl ring $(\mathbf{4 h})$, due to symmetry reasons, negative or positive values of $\tau 2$ leads to the same conformation of $R_{1}$, thus, only positive values are reported in the corresponding tables. By consequence, for these compounds, just $\tau 3$ (positive or negative) values are considered in the classification in to sub-families (i.e., $A=\tau 3+$, $B=\tau 3-)$.

In Table 3 are reported the results obtained for the most active compound of the series, $\mathbf{4 k}$, while the complete set of results for compounds $\mathbf{4 a - x}$ is reported in Tables S1-S24. 
<smiles>COc1ccc(Br)c(C(=O)N2CCN(S(=O)(=O)O)CC2)c1</smiles>

\begin{tabular}{|c|c|c|c|c|}
\hline \multirow[t]{2}{*}{ Cmp } & \multirow[t]{2}{*}{$\mathbf{R}_{1}$} & \multicolumn{3}{|c|}{$\mathrm{Gl}^{\mathrm{a}}(\%)$ at $25 \mu \mathrm{M}$} \\
\hline & & Mean & Sem & t-test \\
\hline $4 a$ & & $30.33^{*}$ & 9.53 & 0.0422 \\
\hline $4 b$ & & $46.27^{* *}$ & 11.01 & 0.0024 \\
\hline $4 c$ & & $60.95^{+*}$ & 0.83 & 0.0005 \\
\hline $4 d$ & & $37.17^{* *}$ & 16.30 & 0.0032 \\
\hline $4 e$ & & $55.59^{* * *}$ & 2.95 & 0.0000 \\
\hline $4 f$ & & $35.73^{* * *}$ & 5.64 & 0.0006 \\
\hline $4 g$ & & $55.24^{*}$ & 6.39 & 0.0390 \\
\hline $4 \mathrm{~h}$ & & 11.11 & 23.06 & 0.3537 \\
\hline $4 i$ & & $67.93^{* *}$ & 4.72 & 0.0027 \\
\hline $4 j$ & & $38.61^{* *}$ & 12.35 & 0.0060 \\
\hline $4 k$ & & $85.29^{*}$ & 3.68 & 0.0158 \\
\hline $4 !$ & & 32.37 & 4.96 & 0.0893 \\
\hline $4 m$ & & $65.79^{* * *}$ & 6.98 & 0.0002 \\
\hline $4 n$ & & $58.01^{* * *}$ & 6.35 & 0.0001 \\
\hline 40 & & 60.31 & 6.20 & 0.1675 \\
\hline $4 p$ & & $76.77^{* *}$ & 3.31 & 0.0025 \\
\hline $4 q$ & & 2.81 & 2.81 & 0.4090 \\
\hline $4 r$ & & $43.79^{* * *}$ & 4.02 & 0.0004 \\
\hline $4 \mathrm{~s}$ & & 3.82 & 2.74 & 0.2720 \\
\hline $4 t$ & & $22.43^{*}$ & 7.24 & 0.0156 \\
\hline $4 u$ & & $57.29^{*}$ & 3.46 & 0.0135 \\
\hline
\end{tabular}




\begin{tabular}{|c|c|c|c|c|}
\hline $4 v$ & & $28.03^{* *}$ & 1.41 & 0.0029 \\
\hline $4 w$ & $\|$ & $48.61^{*}$ & 10.40 & 0.0301 \\
\hline $4 x$ & & $28.38^{* *}$ & 9.19 & 0.0124 \\
\hline
\end{tabular}

${ }^{a} \mathrm{Gl}$-growth inhibition; C4-2 Prostate cancer cell line; ${ }^{*} \mathrm{p}<0.05 ;{ }^{* *} \mathrm{p}<0.01 ;{ }^{* * *} \mathrm{p}<0.001$

Table 2: In vitro Growth Inhibition (GI) of C4-2 prostate cancer cells by the tested compounds.<smiles>COc1ccc(Br)c(C(=O)N2CCN(S(=O)(=O)c3ccccc3C(F)(F)F)CC2)c1</smiles>

\begin{tabular}{|c|c|c|c|c|c|}
\hline \multirow[t]{2}{*}{ Fam } & \multirow[t]{2}{*}{$\Delta \mathrm{E}_{\mathrm{GM}}{ }^{a}(\mathrm{kcal} / \mathrm{mol})$} & \multicolumn{4}{|c|}{$\left({ }^{\circ}\right)$} \\
\hline & & $\mathrm{T} 1^{c}$ & $\mathrm{~T} 2^{d}$ & $\mathrm{~T} 3^{\mathrm{e}}$ & $\mathrm{T} 4^{f}$ \\
\hline $\mathrm{III}_{\mathrm{D}}$ & $0.00-0.80$ & -71 & -49 & -65 & -1 \\
\hline $\mathrm{II}_{\mathrm{A}}$ & $0.02-0.39$ & -166 & 71 & 118 & 2 \\
\hline$\|_{B}$ & $0.05-0.64$ & -166 & 71 & -64 & -1 \\
\hline $\mathrm{III}_{\mathrm{c}}$ & $0.18-0.55$ & -71 & -49 & 118 & 2 \\
\hline$I_{A}$ & $0.23-0.45$ & 68 & 100 & 114 & 1 \\
\hline$I_{c}$ & $0.27-0.49$ & 70 & -100 & 115 & 1 \\
\hline$I_{B}$ & $0.40-1.08$ & 68 & 100 & -112 & -6 \\
\hline$I_{D}$ & $0.50-0.57$ & 71 & -100 & -64 & -2 \\
\hline$\|_{D}$ & $0.84-1.63$ & -154 & -155 & -66 & -1 \\
\hline $\mathrm{III}_{\mathrm{B}}$ & $0.90-1.69$ & -75 & 155 & -65 & -1 \\
\hline $\mathrm{II}_{\mathrm{c}}$ & $1.01-1.39$ & -155 & -155 & 118 & 2 \\
\hline$I \mathbf{V}_{\mathrm{D}}$ & $1.05-1.24$ & -119 & -160 & -65 & -1 \\
\hline $\mathrm{III}_{\mathrm{A}}$ & $1.06-1.44$ & -75 & 155 & 118 & 2 \\
\hline $\mathbf{I V} \mathbf{c}_{\mathrm{c}}$ & $1.27-1.49$ & -120 & -160 & 119 & 2 \\
\hline
\end{tabular}

${ }^{a}$ The values reported refer to the lowest and the highest energy conformers of the family. ${ }^{b}$ The values reported refer to the lowest energy conformers of the family. ${ }^{c} \mathrm{~T} 1$ torsion angle is calculated considering e, f, g, and $\mathrm{h}$ atoms. ${ }^{d} \mathrm{~T} 2$ : $\mathrm{f}, \mathrm{g}, \mathrm{h}$, and i atoms. ${ }^{\mathrm{e}} \mathrm{T}$ : a, b, c, and d atoms. ${ }^{f} \mathrm{~T} 4: \mathrm{j}, \mathrm{k}, \mathrm{I}$, and $\mathrm{m}$ atoms.

Table 3: Conformational families of $\mathbf{4 k}$ considering MM conformers within $5 \mathrm{kcal} / \mathrm{mol}$ from the global minimum.

All compounds, with the exception of $\mathbf{4 k}$ and $\mathbf{4 b}$, present a conformational preference for the family of conformers named I $\left(\tau_{1}\right.$ about $\left.70^{\circ}\right)$, closely followed by family IV $\left(\tau_{1}\right.$ about $\left.-80^{\circ}\right)$ and, then, at about $2 \mathrm{kcal} / \mathrm{mol}$ from the GM, by families II and III $\left(\tau_{1}\right.$ about $-165^{\circ}$ and $-68^{\circ}$, respectively). Importantly, if we consider the position of the sulphur bound oxygen atoms with respect to the piperazine nitrogen substituents, family I and IV present the anti and the fully eclipsed conformations, respectively (Figure 3B). Thus, in agreement with previously reported results on benzosulfonamide derivatives [3537 the two most favoured families of conformers are I and IV, with family I (i.e., anti conformation of the oxygen atoms with respect to the piperazine nitrogen substituents) representing the GM family, as found in the crystal structure of $\mathrm{N}, \mathrm{N}$-dimethyltoluene-p-sulfonamide [38].

As expected, $\tau 2$ values affect the conformational behaviour of compounds bearing ortho-substituted $\mathrm{R}_{1}$, particularly of $\mathbf{4 k}$, which is characterized by a bulkier substituent (Table 2). However, this is true only within conformer families II and III (Table 3). A similar, although smaller, effect is observed when a bulky meta-substituted $\mathrm{R}_{1}$ is present (41; Table S12, SI), affecting, in this case, the conformational preference within family IV of conformers. On the other hand, the energetically favoured orientation of $R(\tau 3)$ depends on the nature of $R_{1}$, thus it varies from a compound to the other, although just contributing for about $0.4 \mathrm{kcal} / \mathrm{mol}$ to the overall conformational energy. Finally, the orientation of the meta-methoxy substituent of $\mathrm{R}$ resulted to shift between the two co-planar conformations with respect to the phenyl ring, corresponding to values of about $0^{\circ}$ or $180^{\circ}$ of the related torsion angle (named $\tau 4$ ). If we exclude some exception in family $\mathrm{IV}_{\mathrm{B}}$ and $\mathrm{III}_{\mathrm{B}}$, the lowest energy conformers of $4 \mathbf{a}-\mathbf{x}$ presented a $\tau 4$ value of about $0^{\circ}$, although the alternative orientation of the methoxy substituent of $\mathrm{R}$ $\left(\tau 4=180^{\circ}\right)$ is anyway just $0.2 \mathrm{kcal} / \mathrm{mol}$ less favoured.

As mentioned above, two exceptions to the common conformational behaviour showed by compounds $\mathbf{4 a - x}$ are represented by compounds $\mathbf{4 k}$ and $\mathbf{4 b}$. As expected, a strong influence on the conformational behaviour of $\mathbf{4 b}$ is due to the presence of a benzyl ring as $R_{1}$, which in all the other derivatives is a(substituted) phenyl ring (Table 2). Thus, on one hand, due to the steric hindrance of the $\mathrm{R}_{1}$ substituent, only conformers belonging to family I and IV resulted energetically allowed (Figure 3B), with this latter being the GM family. On the other hand, due to the introduction of an $\mathrm{sp}^{3}$ carbon atom linking the aromatic $\mathrm{R}_{1}$ moiety to the sulphonamide function, the conformational preference 


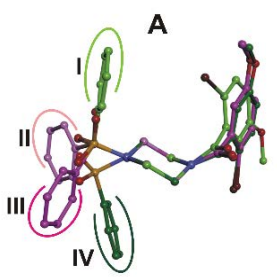

B

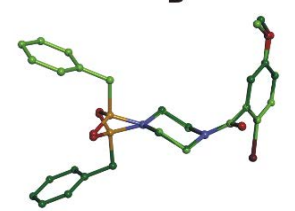

C

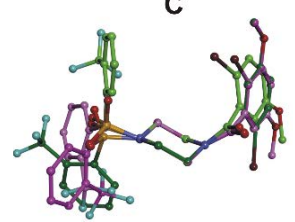

Figure 3: Molecular structures of the calculated families of conformers of $4 a$ (A), $\mathbf{4 b}(\mathrm{B})$ and $\mathbf{4 k}(\mathrm{C})$, superimposed by piperazine carbon atoms. Molecule carbon atoms are coloured according to the conformer family classification (I=light green, II=pink, III=magenta, and IV=dark green). Conformer families are evidenced and labelled in (A).

of $4 \mathrm{~b}$ strongly depends upon $\mathrm{R}_{1}$ rotation, with the lowest energy conformers showing, just in the case of this compound, a $\tau 2$ torsion angle value of $180^{\circ}$ (Figure 3B and Table S2).

Compound $\mathbf{4 k}$ represents the other exception, being also the most active compound of the series, and it is characterized by an orthotrifluoromethyl-substituted phenyl ring as $\mathrm{R}_{1}$. In the case of $\mathbf{4 k}$, the GM conformer belongs to the III subfamily, closely followed by the conformers of subfamily $\mathrm{II}_{\mathrm{A}}, \mathrm{II}_{\mathrm{B}}$ and $\mathrm{III}_{\mathrm{C}}$, in turn, followed by family I (within $0.5 \mathrm{kcal} / \mathrm{mol}$ from the GM), and, at about $1 \mathrm{kcal} / \mathrm{mol}$ from the GM, by the conformers of the remaining subfamilies. Thus, the conformational behaviour of $\mathbf{4 k}$ appears to be significantly different from those of the other compounds, with families II and III becoming energetically preferred over families I and IV, depending on the orientation of the trifluoromethyl substituent. It is noteworthy, that, despite being characterized by different $\tau 2$ values, when superimposed by the piperazine ring, the lowest energy conformers of family III and II of $\mathbf{4 k}$ present the $\mathrm{R}_{1}$ substituent occupying the same spatial position (Figure $3 \mathrm{C}$ and Table 3 ).

To investigate the peculiar conformational preference of $\mathbf{4 b}$ and, especially, $\mathbf{4 k}$ with respect to the other derivatives, the lowest energy MM conformer of each family of $\mathbf{4 a}, \mathbf{4} \mathbf{b}, \mathbf{4 e}$, and $\mathbf{4 k}$ were subjected to DFT full optimization calculations at the B3LYP/6-31+G(d,p) $[29,30]$ Gaussian 09 package [28]. Moreover, to evaluate the influence of the orientation of the ortho-trifluoromethyl substituent of $\mathbf{4 k}$, we included in DFT calculations the lowest energy conformers of family I-III presenting the opposite orientation of the $\mathrm{R}_{1}$ substituent ( $\tau 2$ torsion angle); while, to check the energy difference between the two possible $\mathrm{R}$ orientation ( $\tau 3$ torsion angle), the lowest energy conformer of the $I_{B 180}$ subfamily of $\mathbf{4 b}$ was also included (Table 4 ).

The conformational preference of $\mathbf{4} \mathbf{k}$ was confirmed compared to $\mathrm{MM}$ results, with the GM belonging to family $\mathrm{III}_{\mathrm{D}}$ (negative $\tau 2$ value), followed, within $0.5 \mathrm{kcal} / \mathrm{mol}$ from the $\mathrm{GM}$, by subfamily $\mathrm{I}_{A}, \mathrm{II}_{A}$, and $I_{C}$ (Figure 4), while the alternative orientation of the trifluoromethyl substituent of $4 \mathbf{k}$ (subfamily $\mathrm{III}_{\mathrm{B}}$, positive $\tau 2$ value) results in to a conformer with a $\Delta \mathrm{G}_{\mathrm{GM}}>2 \mathrm{kcal} / \mathrm{mol}$. Similar results were obtained for the lowest energy conformer of family $\mathrm{II}_{\mathrm{D}}$ (positive $\tau 2$ value) with respect to that of family $\mathrm{II}_{\mathrm{A}}$ (negative $\tau 2$ value), thus, increasing the influence of the orientation of the ortho-substituent on the conformational preference of $\mathbf{4 k}$ with respect to MM results.

Remarkably, the DFT full optimization of the MM lowest energy conformer of family IV, belonging, in this case, to $\mathrm{IV}_{\mathrm{D}}$ subfamily, led to the lowest energy conformer of another family (II $I_{D}$ ) (Table 4). Similarly, DFT calculations on $\mathbf{4 a}$ and $\mathbf{4 e}$ confirm the conformational trend obtained by MM when we consider families I-III (as also resulted extending DFT calculations to 4o), but gave very different results for family IV (Table 4). In particular, the lowest energy conformer of family IV of $\mathbf{4 a}$ (subfamily $\mathrm{IV}_{\mathrm{B}}$; which closely follows the GM conformer according to MM results; Table S1, SI) became the less favoured of the considered conformers, while the corresponding conformer of $4 \mathbf{e}$ (subfamily $\mathrm{IV}_{\mathrm{D}}$; Table S5, SI) moves, after DFT optimization, to the conformer belonging to family III ${ }_{D}$ (Table 4 ). To further investigate this issue, DFT calculations were also performed on the MM lowest energy conformers of family I and IV of compounds $4 \mathbf{c}, 4 \mathbf{h}, 4 \mathbf{l}, 4 \mathbf{p}, 4 \mathrm{~s}$, and 4w. Results confirm the family I conformer as the GM, as obtained by $\mathrm{MM}$, but with the family IV conformer showing a $\Delta \mathrm{G}_{\mathrm{GM}}$ of more than 2 $\mathrm{kcal} / \mathrm{mol}$, as occurred for $\mathbf{4 a}$ (Table 4). Finally, the results obtained for the $\mathrm{I}_{\mathrm{A} 180}$ and $\mathrm{I}_{\mathrm{B} 180}$ conformers of $\mathbf{4 b}$ and the $\mathrm{I}_{\mathrm{A}}$ and $\mathrm{I}_{\mathrm{B}}$ conformers of $\mathbf{4 w}$, showed an energy difference of less than $0.2 \mathrm{kcal} / \mathrm{mol}$ between the two possible orientations of the di-substituted phenyl ring of $\mathrm{R}$ (positive/ negative $\mathrm{t} 3$ value; Table 4 ), in agreement with the conformational search results (Table S1-S24, SI).

In all cases, the GM conformers identified by MM were all confirmed by DFT calculations with the only exception of $\mathbf{4 b}$, whose GM still belongs to family IV but presenting a $\tau 2$ angle value of $60^{\circ}$ (family $\mathrm{IV}_{\mathrm{B}}$ instead of $\mathrm{IV}_{\mathrm{B} 180}$ ). This is particularly important for sulphonamide derivatives which present electron withdrawing substituent on the sulphur atom, since it has been previously demonstrated that, in this case, the different conformers can be considered as rather rigid molecules due to a high barrier of internal rotation around the S-N bond [35], and that this effect is enhanced in the presence of an ortho-substituted phenyl ring with respect to unsubstituted or para-substituted ones [37]

At this stage, in order to properly evaluate the effect of electronic parameters on biological activity, we extended the DFT full optimization

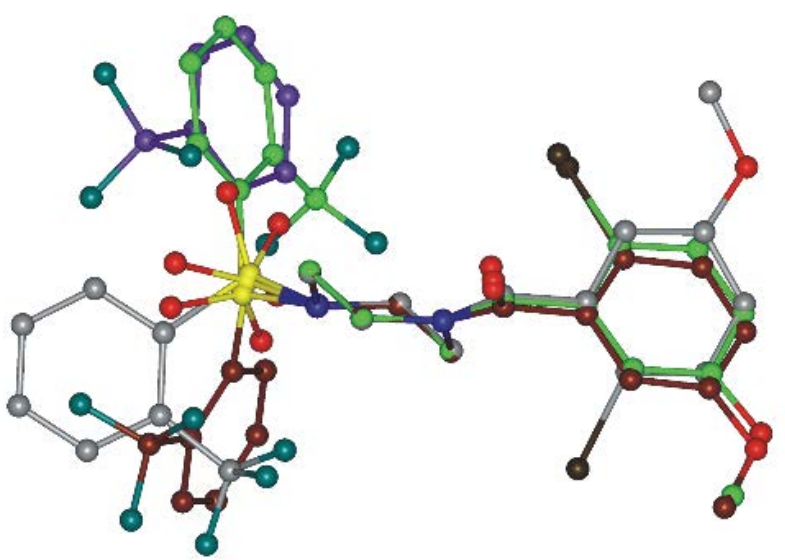

Figure 4: 4k lowest energy conformers (within $0.5 \mathrm{kcal} / \mathrm{mol}$ from the $\mathrm{GM}$ ) resulting after DFT full optimization. Carbons are coloured according to conformer family: $I_{A}$ (green), $I_{C}$ (violet), $I_{A}$ (brown), and III $I_{D}$ (gray; GM conformer). 


\begin{tabular}{|c|c|c|c|c|c|c|}
\hline \multirow[t]{2}{*}{ Cmp } & \multirow[t]{2}{*}{ Fam } & \multirow[t]{2}{*}{$\begin{array}{c}\Delta \mathrm{E}_{\mathrm{GM}} \\
\text { (kcal/mol) }\end{array}$} & \multicolumn{4}{|c|}{$\begin{array}{c}\text { Torsion Angles } \\
\left({ }^{\circ}\right)\end{array}$} \\
\hline & & & $\mathrm{T} 1$ & $\mathrm{~T} 2$ & T3 & $\mathrm{T} 4$ \\
\hline \multirow[t]{4}{*}{$4 a$} & $I_{A}$ & 0.00 & 68.94 & 88.96 & 81.00 & -1.50 \\
\hline & $\mathrm{III}_{\mathrm{B}}$ & 0.98 & -73.91 & 112.68 & -73.91 & 1.44 \\
\hline & $\|_{B}$ & 1.09 & -154.06 & 68.38 & -76.36 & 1.88 \\
\hline & $\mathrm{IV}_{\mathrm{B}}$ & 2.70 & -80.04 & 90.69 & -75.61 & 2.19 \\
\hline \multirow[t]{4}{*}{$4 b$} & $\mathrm{IV}_{\mathrm{B}}$ & 0.00 & -96.81 & 59.65 & -76.51 & 2.05 \\
\hline & $I_{A 180}$ & 0.36 & 72.08 & 179.81 & 83.10 & -1.25 \\
\hline & $I_{B 180}$ & 0.55 & 72.53 & 178.98 & -74.16 & 2.21 \\
\hline & $I V_{B 180}$ & 0.76 & -137.43 & -177.53 & -77.13 & 1.61 \\
\hline \multirow[t]{2}{*}{$4 c$} & $\mathrm{I}_{\mathrm{B}}$ & 0.00 & 70.35 & 91.02 & -74.64 & 2.78 \\
\hline & $I_{B}$ & 2.49 & -78.37 & 88.81 & -76.46 & 2.06 \\
\hline \multirow[t]{4}{*}{$4 e$} & $I_{A}$ & 0.00 & 66.37 & 71.27 & 80.90 & -1.43 \\
\hline & $\mathrm{III}_{\mathrm{D}}$ & 0.49 & -82.33 & -61.99 & -77.11 & 1.86 \\
\hline & $11 I_{D}{ }^{a}$ & 0.49 & -82.34 & -61.96 & -77.10 & 1.81 \\
\hline & $\mathrm{II}_{\mathrm{B}}$ & 0.72 & -144.93 & 62.59 & -75.95 & 2.11 \\
\hline \multirow[t]{2}{*}{$4 h$} & $I_{A}$ & 0.00 & 70.43 & 88.87 & 81.27 & -1.39 \\
\hline & $\mathrm{IV}_{\mathrm{B}}$ & 2.29 & -78.86 & 97.33 & -75.32 & 2.27 \\
\hline \multirow[t]{6}{*}{$4 k$} & $\mathrm{III}_{\mathrm{D}}$ & 0.00 & -78.50 & -53.68 & -75.27 & 1.85 \\
\hline & $I_{A}$ & 0.22 & 69.75 & 95.49 & 82.88 & -1.49 \\
\hline & $\mathrm{II}_{\mathrm{A}}$ & 0.40 & -143.63 & 76.22 & 77.79 & -1.98 \\
\hline & $I_{c}$ & 0.51 & 79.53 & -93.73 & 80.81 & -181 \\
\hline & $\mathrm{III}_{\mathrm{B}}$ & 2.14 & -82.68 & 154.84 & -77.92 & 1.38 \\
\hline & $\mathrm{II}_{\mathrm{D}}{ }^{\mathrm{a}}$ & 2.19 & -146.11 & -154.12 & -77.58 & 1.66 \\
\hline \multirow[t]{2}{*}{$4 I$} & $I_{A}$ & 0.00 & 70.72 & 87.84 & 84.89 & -1.34 \\
\hline & $I V_{D}$ & 2.56 & -80.47 & -85.12 & -79.04 & 2.21 \\
\hline \multirow[t]{3}{*}{40} & $I_{B}$ & 0.00 & 69.08 & 89.34 & -75.79 & 2.21 \\
\hline & $\mathrm{II}_{\mathrm{A}}$ & 0.76 & -154.03 & 71.27 & 77.62 & -2.00 \\
\hline & $\mathrm{III}_{\mathrm{B}}$ & 0.81 & -73.16 & 114.37 & -76.50 & 1.82 \\
\hline \multirow[t]{2}{*}{$4 p$} & $I_{B}$ & 0.00 & 68.75 & 88.65 & -75.52 & 2.15 \\
\hline & $\mathrm{IV}_{\mathrm{B}}$ & 2.50 & -76.30 & 91.84 & -77.46 & 178.29 \\
\hline \multirow[t]{2}{*}{$4 s$} & $\mathrm{I}_{\mathrm{B}}$ & 0.00 & 70.62 & 89.11 & -74.70 & 2.17 \\
\hline & $\mathrm{IV}_{\mathrm{B}}$ & 2.33 & -81.72 & 90.20 & -76.30 & 177.93 \\
\hline \multirow[t]{3}{*}{$4 w$} & $I_{B}$ & 0.00 & 66.83 & 69.45 & -75.16 & 2.24 \\
\hline & $I_{A}$ & 0.13 & 66.91 & 69.62 & 80.35 & -1.56 \\
\hline & $\mathrm{IV}_{\mathrm{D}}$ & 1.87 & -71.79 & -66.59 & -77.97 & 2.03 \\
\hline
\end{tabular}

aThe starting MM conformer belongs to family $I V_{D}$.

Table 4: $\Delta \mathrm{E}_{\mathrm{GM}}$ values $(\mathrm{kcal} / \mathrm{mol})$ and torsion angle values (degrees) of $\mathbf{4 a}-\mathrm{c}, \mathbf{4 e}, \mathbf{4 h}, \mathbf{4 k}, \mathbf{4}, \mathbf{4 0}, \mathbf{4 p}, \mathbf{4 s}$, and $4 \mathbf{w}$ conformers obtained after DFT optimization.

calculations to the GM conformers of all compounds (results obtained for compounds $4 d, 4 f, 4 g, 4 i, 4 j, 4 m, 4 n, 4 q, 4 r, 4 t, 4 u, 4 v$, and $4 x$ are reported in Table S25, SI) and the atomic charges derived from the NBO population analysis were used to calculate the dipole moment of the substituent $\mathrm{R}_{1}$ (Figures 5 and 6).

As can be evicted from Figure 5, particularly evident is the effect of polarization in affecting the activity of compounds $4 \mathrm{~h}$ vs $4 \mathrm{e}$ and $\mathbf{4 g}$ (Table 2); regarding $\mathbf{4 k}$, which also present a similar dipole compared to $4 \mathbf{e}$ and $\mathbf{4 g}$, conformational parameters likely play an additional role on its higher biological activity. On the contrary, the meta-substituted analogue of $\mathbf{4 k}$, compound $\mathbf{4 l}$, despite presenting a similar $\mathrm{R}_{1}$ dipole (data not shown), is endowed by poor biological activity (Table 2). Thus, a proper $\mathrm{R}_{1}$ polarization is necessary, likely to allow the right orientation in the target binding site, however it is not sufficient to improve biological activity. This suggests the presence of a spatially defined(specific) interaction with the biological target involving the electron-withdrawing ortho-substituent of $\mathrm{R}_{1}$. The analysis of the results obtained for compounds $\mathbf{4 u - x}$ (Table 2), characterized by the

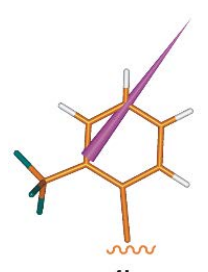

$4 \mathbf{k}$

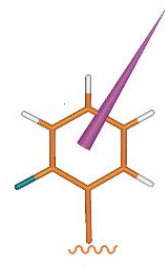

$4 e$

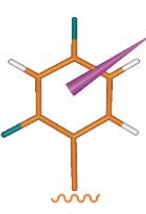

$4 \mathrm{~g}$

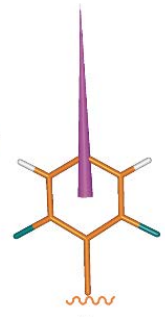

4h
Figure 5: $\mathrm{R}_{1}$ dipole moment vectors of compounds $4 \mathrm{e}, \mathbf{4 g}, \mathbf{4 h}$, and $\mathbf{4 k}$ calculated on the GM conformers optimized at the DFT level. Dipole moments are colored in magenta and represented by solid cones, pointing from the negative to the positive pole of the dipole. Atoms are colored by atom type ( $\mathrm{C}=$ orange; $\mathrm{N}=$ blue; $\mathrm{O}=$ red; $\mathrm{F}=$ dark green; $\mathrm{Cl}$; light green; $\mathrm{Br}=$ brown; $\mathrm{H}=$ =white).

presence of a 2 - or 3 -thiophenyl substituent ( $4 \mathbf{u}$ and $4 \mathbf{v}$, respectively) and a 2 - or 3 -furanyl substituent ( $\mathbf{4} \mathbf{w}$ and $\mathbf{4 x}$, respectively), supports this hypothesis (data not shown). 


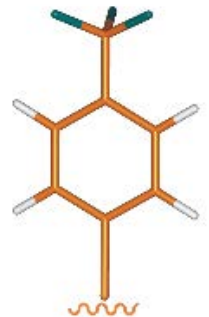

$4 \mathrm{~m}$

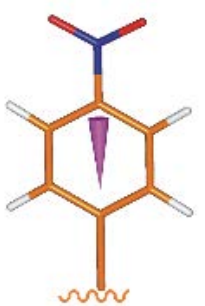

4s

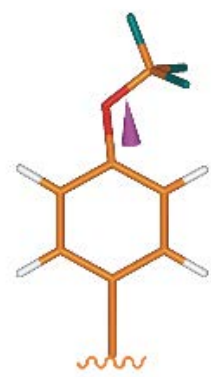

$4 n$

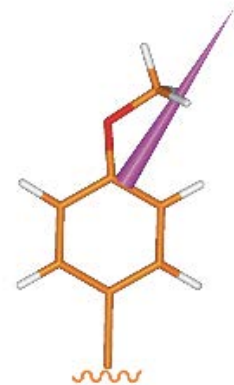

$4 \mathrm{t}$

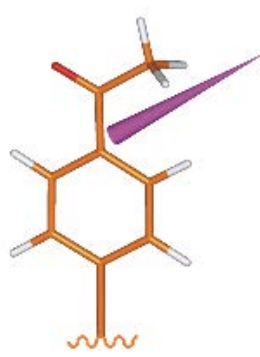

$4 r$

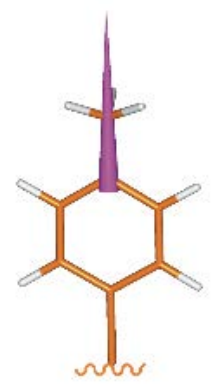

$4 \mathrm{q}$
Figure 6: $R_{1}$ dipole moments vectors of compounds $4 m, 4 n, 4 q, 4 r, 4 s$, and $4 t$ calculated on the GM conformers optimized at the DFT level. Dipole moments are colored in magenta and represented by solid cones, pointing from the negative to the positive pole of the dipole. Atoms are colored by atom type ( $\mathrm{C}=$ orange; $\mathrm{N}=$ blue; $\mathrm{O}=$ red; $\mathrm{F}=$ dark green; $\mathrm{Cl}$; light green; $\mathrm{Br}=$ brown; $\mathrm{H}=$ white)

On the other hand, when shifting to the polarization of the parasubstituted $\mathrm{R}_{1}$ analogues other interesting considerations can be done (Figure 6).

Also in this case the presence of electron withdrawing substituents, such as in $\mathbf{4 m}, \mathbf{4 n}$, and $\mathbf{4 r}$ leads to an improvement of the biological activity compared to $\mathbf{4 a}$, while the opposite is true for substituents such as a methoxy (4t) or a methyl (4q; Table 2). However, by increasing the polarization of $\mathrm{R}$, the biological activity progressively decrease $(\mathbf{4 r}<\mathbf{4 n}<\mathbf{4 m})$, as it also occurs when the $R_{1}$ dipole is oriented in the opposite direction as in $\mathbf{4 s}$. In this view, the activity improvement of $\mathbf{4 i}$ (para-Br) with respect to $\mathbf{4 d}$ (para-F) and $\mathbf{4 j}$ (para-Cl) seems not to be connected to $\mathrm{R}_{1}$ polarization but rather to the increased dimension of the bromine atom. A similar SAR can be observed by comparing $4 \mathbf{d}$ to $\mathbf{4 m}$ (Table 2). In general, the size of the para-substituent seems to be crucial for biological activity (4q vs 4o; Table 2 ) with bulky hydrophobic substituents leading to increased potency $(\mathbf{4 p}>\mathbf{4 c}>\mathbf{4 0}>\mathbf{4 r})$.

In Figure 7 it is reported the superimposition of the DFT GM conformers of the compounds presenting favourable $R_{1}$ substituents with respect to the unsubstituted phenyl ring of $4 \mathbf{a}$ (Figure 7A), the compounds whose $\mathrm{R}_{1}$ do not improve the biological activity with respect to $4 \mathrm{a}$ (Figure $7 \mathrm{~B}$ ), and the compounds presenting unfavourable $\mathrm{R}_{1}$ substitution compared to $\mathbf{4 a}$ (Figure 7C). Interestingly, in addition to the above discussed favourable steric effects at the para-position of the phenyl ring of $R_{1}$, another sterically favourable region occupied by both, the DFT GM conformers of $\mathbf{4 k}$ and $\mathbf{4 b}$, can be observed.

\section{Conclusion}

In summary, we report herein the synthesis of a series of $\mathbf{4 a - x}$ derivatives by a multistep reaction starting from piperazine, 2-bromo-5methoxybenzoic acid and different aryl or heteroarylsulfonyl chlorides.

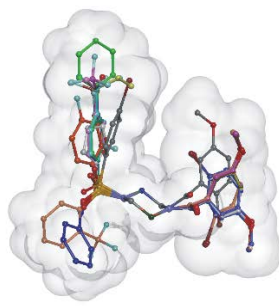

B

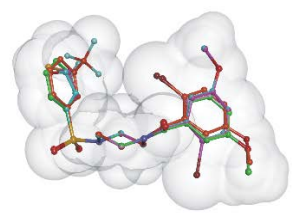

C

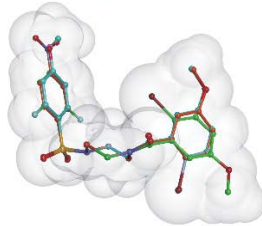

Figure 7: Superimposition by the piperazine ring carbons of the DFT GM conformers of: A) $\mathbf{4 b}$ (cyan), $\mathbf{4 c}$ (green), $\mathbf{4 d}$ (dark blue), $\mathbf{4 e}$ (dark green), $\mathbf{4 g}$ (orange), 4i (grey), 4j (violet), 4k (peach), 4m (burgundy), 4n (magenta), 40 (pale light), $\mathbf{4 p}$ (light blue), $\mathbf{4 r}$ (pink), $\mathbf{4 u}$ (green water), $\mathbf{4 w}$ (white); B): $\mathbf{4 a}$ (green), 4f (pink), $\mathbf{4 l}$ (orange), 4v (magenta), 4x (cyan); C) 4h (green), 4q (pink), 4s (orange), 4t (cyan). Molecules are displayed as sticks, hydrogen are omitted for clarity of presentation. The Van der Waals volumes of the compounds is represented as transparent surface.

These compounds were obtained in good yields and were characterized by ${ }^{19} \mathrm{~F},{ }^{1} \mathrm{H},{ }^{13} \mathrm{C}$ NMR spectroscopies, HRMS and by HPLC. Moreover, their antiproliferative activity against C4-2 prostate cancer cells were evaluated by measuring the percentage of BrdU-positive proliferating cells 48 hours after incubation. Among the series, four compounds (4i, $\mathbf{4 k}, \mathbf{4 m}, \mathbf{4 p}$ ) exhibited significant growth inhibitory activities against C4-2 prostate cancer cells.

The 3D-SAR analysis evidenced that the size and the polarizability of the ortho- and para-substituent of $\mathrm{R}_{1}$ seem to be crucial for biological activity suggesting the presence of a spatially defined interaction with the putative biological target involving the electron-withdrawing orthosubstituent and the bulky hydrophobic para-substituent of $\mathrm{R}_{1}$.

\section{Supplementary Material}

Computational studies of all compounds are described in SI. The description of all compounds and ${ }^{1} \mathrm{H}-\mathrm{NMR}$ and ${ }^{13} \mathrm{C}-\mathrm{NMR}$ for target compounds $4 \mathbf{i}, \mathbf{k}, \mathbf{m}, \mathbf{p}$ are described in SI.

\section{Conflict of Interest}

The authors declare that they have no conflict of interest. We gratefully thank the french Institute of national cancer (INCA) and the French Fondation pour la Recherche Medicale (FRM) for their financial support.

\section{References}

1. Nelson WG, De Marzo AM, Isaacs WB (2003) Prostate cancer. N Engl J Med 349: 366-381.

2. Edwards BK, Brown ML, Wingo PA, Howe HL, Ward E, et al. (2005) Annual Report to the Nation on the Status of Cancer, 1975-2002, Featuring PopulationBased Trends in Cancer Treatment. J. Natl. Cancer Inst 97: 1407-1427.

3. Mundy GR (2002) Metastasis to bone: causes, consequences and therapeutic opportunities. Nat Rev Cancer 2: 584-593. 
Citation: Benfodda Z, Fritz V, Henriquet C, Fattorusso C, Cebrián-Torrejón G, et al. (2017) Synthesis, Anticancer Activity and Computational SAR Analysis of Acylsulfonylpiperazines Derivatives. Med Chem (Los Angeles) 7: 257-267. doi: 10.4172/2161-0444.1000466

4. Bracarda S, de Cobelli O, Greco C, Prayer-Galetti T, Valdagni R, et al. (2005) Cancer of the prostate. Crit Rev Oncol Hematol 56: 379-396.

5. Guo Z, Dai B, Jiang T, Xu K, Xie Y, et al. (2006) Regulation of androgen receptor activity by tyrosine phosphorylation. Cancer Cell 10: 309-319.

6. Heinlein CA, Chang C (2004) Androgen receptor in prostate cancer. Endocr Rev 25: 276-308.

7. Ghosh PM, Malik SN, Bedolla RG, Wang Y, Mikhailova M, et al. (2005) Signal transduction pathways in androgen-dependent and -independent prostate cancer cell proliferation. Endocr Relat Cancer 12: 119-134.

8. Kokontis JM, Hsu S, Chuu CP, Dang M, Fukuchi J, et al. (2005) Role of androgen receptor in the progression of human prostate tumor cells to androgen independence and insensitivity. Prostate 65: 287-298.

9. Schulze H, Isaacs J, Senge T (1987) Inability of complete androgens blockade to increase survival of patients with advanced prostatic cancer as compared to standard hormonal therapy. J. Urol 137: 909-911.

10. Perry CM, McTavish D (1995) Estramustine phosphate sodium. A review of its pharmacodynamic and pharmacokinetic properties, and therapeutic efficacy in prostate cancer. Drugs Aging 7: 49-74.

11. Petrylak DP (2005) Chemotherapy for androgen-independent prostate cancer World J Urol 23: 10-13.

12. Culine HB, Cristol JP, Michel F, Sardet C, Fajas L, et al. (2010) Abrogation of de novo lipogenesis by stearoyl-CoA desaturase 1 inhibition interferes with oncogenic signaling and blocks prostate cancer progression in mice. Mol. Cancer Ther 9: 1740-1754.

13. Benfodda Z, Fritz V, Fajas L (2012) Preparation of piperazine derivatives as inhibitors of lipogenesis in prostate. Cancer. WO 2011030312.

14. Foye WO, Lemke TL, William DA (1995) Principles of medicinal chemistry. 4th edn.

15. Haga N, Ishibashi T, Hara A, Abiko Y (1985) Effect of NCO-700, an inhibitor of protease, on myocardial $\mathrm{pH}$ decreased by coronary occlusion in dogs. Pharmacology 31: 208-217.

16. Wilson WD, Barton HJ, Tanious FA, Kong SB, Strekowski L (1990) The interaction with DNA of unfused aromatic systems containing terminal piperazino substituents: Intercalation and groove-binding. Biophys. Chem 35 227-243

17. Hulme C, Cherrier MP (1999) Novel applications of ethyl glyoxalate with the Ugi MCR. Tetrahedron Lett 40: 5295-5299.

18. Yoshida M, Maehara Y, Sugimachi K (1999) MST-16, A Novel BisDioxopiperazine Anticancer Agents, Ameliorates Doxorubicin-Induced Acute Toxicity While Maintaining Antitumor Afficacy. Clin. Cancer Res 5: 4295-4300.

19. Guo CC, Li HP, Zhang XB (2003) Study on synthesis, characterization and biological activity of some new nitrogen heterocycles porphyrins. Bioorg. Med. Chem 11: 1745-1751

20. Guo CC, Tong RB, Li KL (2004) Chloroalkyl piperazine and nitrogen mustard porphyrins: synthesis and anticancer activity. Bioorg. Med. Chem 12: 2469-2475.

21. Sashida H, Abiko Y (1985) Inhibition with NCO-700, a protease inhibitor, of degradation of cardiac myofibrillar proteins during ischemia in dogs. Biochem Pharmacol 34: 3875-3880.

22. Nomura Y, Yamakawa T, Nishioka K, Omura T, Miyake N, et al. (1995)
Synthesis and structure-activity relationships of 2-(4-benzhydryl-1-piperazinyl)1-phenylethanols as new calcium blockers. Chem. Pharm. Bull 43: 241-246.

23. Kimura M, Masuda T, Yamada K, Mitani M, Kubota N, et al. (2003) Novel diphenylalkyl piperazine derivatives with high affinities for the dopamine transporter. Bioorg. Med. Chem 11: 3953-3963.

24. Dorsey BD, Levin RB, McDaniel SL, Vacca JP, Guare JP, et al. (1994) L-735,524: the design of a potent and orally bioavailable HIV protease inhibitor J Med Chem 37: 3443-3451.

25. Rossen K, Weissman SA, Sager J, Reamer RA, Askin D, et al. (1995) Asymmetric hydrogenation of tetrahydropyrazines: Synthesis of (S)-piperazine2-tert-butylcarboxamide, an intermediate in the preparation of the HIV protease inhibitor indinavir. Tetrahedron Lett 36: 6419.

26. Fletcher R (1980) Unconstrained Optimization. In: Practical Methods of Optimization. John Wiley and Sons. New York, USA.

27. Ewig CS, Berry R, Dinur U, Hill JR, Hwang MJ, et al. (2001) Derivation of class II force fields. VIII. Derivation of a general quantum mechanical force field for organic compounds. J Comput Chem 22: 1782-1800.

28. Becke AD (1993) Density $\square$ functional thermochemistry. III. The role of exact exchange. J. Chem. Phys 98: 5648-5652.

29. Lee C, Yang W, Parr RG (1988) Development of the Colle-Salvetti correlationenergy formula into a functional of the electron density. Phys. Rev. B: Condens. Matter. Mater. Phys 37: 785-789.

30. Reed AE, Weinstock RB, Weinhold F (1985) Natural population analysis. The Journal of Chemical Physics 83: 735-746.

31. Azéma J, Guidetti B, Dewelle J, Le Calve B, Mijatovic T, et al. (2009) 7-((4-substituted)piperazin-1-yl)derivatives of ciprofloxacin: synthesis and in vitro biological evaluation as potential antitumor agents. Bioorg. Med. Chem 17: 5396-5407.

32. Onnis V, Cocco MT, Lilliu V, Congiu C (2008) Synthesis and evaluation of antitumoral activity of ester and amide derivatives of 2-arylamino-6trifluoromethyl-3-pyridinecarboxylic acids. Bioorg. Med. Chem 16: 2367-2378.

33. Nandurdikar RS, Maciag AE, Citro ML, Shami PJ, Keefer LK, et al. (2009) Synthesis and evaluation of piperazine and homopiperazine analogues of JS$\mathrm{K}$, an anti-cancer lead compound. Bioorg Med Chem Lett 19: 2760-2762.

34. Petrov V, Petrova V, Girichev GV, Oberhammer H, Giricheva NI (2006) Molecular structure and conformations of benzenesulfonamide: gas electron diffraction and quantum chemical calculations. J. Org. Chem 71: 2952-2956.

35. Petrov V, Girichev GV, Oberhammer H, Petrova V, Giricheva NI, et al. (2008) Molecular Structure and Conformations of para-Methlybenzene Sulfonamide and ortho-Methylbenzene Sulfonamide: Gas Electron Diffraction and Quantum Chemical Calculations Study. J. Phys. Chem 112: 2969-2976.

36. Borba A, Gomez-Zavaglia A, Fausto R (2013) Conformational landscape photochemistry, and infrared spectra of sulfanilamide. J Phys Chem A 117 704-717.

37. Ruostesuo P, Hakkinen AM, Kivekas R, Sundberg MR (1988) Nmr spectroscopic and X-ray crystallographic studies on some o-NO 2 substituted aromatic sulphur amides. J. Chem. Soc. Perkin Trans 1397-1403.

38. Lyapkalo IM, Reissig HU, Schafer A, Wagner A (2002) Study of Unusually High Rotational Barriers about S-N Bonds in Nonafluorobutane-1-sulfonamides: The Electronic Nature of the Torsional Effect. Helvetica Chimica Acta 85: 4206-4215. 